University of Nebraska - Lincoln

DigitalCommons@University of Nebraska - Lincoln

Papers in Veterinary and Biomedical Science

Veterinary and Biomedical Sciences

Department of

$1-2-2004$

\title{
Decreased shedding of Escherichia coli 0157:H7 by cattle following vaccination with type III secreted proteins
}

\author{
Andrew A. Potter \\ Vaccine and Infectious Disease Organization, University of Saskatchewan, andrew.potter@usask.ca \\ Sandra Klashinsky \\ Vaccine and Infectious Disease Organization, University of Saskatchewan, Saskatoon, SK, Canada \\ Yuling Li \\ University of British Columbia, Vancouver BC, Canada \\ Elizabeth Frey \\ University of British Columbia, Vancouver BC, Canada \\ Hugh Townsend \\ University of Saskatchewan, Saskatoon, SK, Canada
}

See next page for additional authors

Follow this and additional works at: https://digitalcommons.unl.edu/vetscipapers

Part of the Veterinary Medicine Commons

Potter, Andrew A.; Klashinsky, Sandra; Li, Yuling; Frey, Elizabeth; Townsend, Hugh; Rogan, Dragan;

Erickson, Galen E.; Hinkley, Susanne; Klopfenstein, Terry J.; Moxley, Rodney A.; Smith, David R.; and Finlay, B. Brett, "Decreased shedding of Escherichia coli 0157:H7 by cattle following vaccination with type III secreted proteins" (2004). Papers in Veterinary and Biomedical Science. 93.

https://digitalcommons.unl.edu/vetscipapers/93

This Article is brought to you for free and open access by the Veterinary and Biomedical Sciences, Department of at DigitalCommons@University of Nebraska - Lincoln. It has been accepted for inclusion in Papers in Veterinary and Biomedical Science by an authorized administrator of DigitalCommons@University of Nebraska - Lincoln. 


\section{Authors}

Andrew A. Potter, Sandra Klashinsky, Yuling Li, Elizabeth Frey, Hugh Townsend, Dragan Rogan, Galen E. Erickson, Susanne Hinkley, Terry J. Klopfenstein, Rodney A. Moxley, David R. Smith, and B. Brett Finlay 
Published in Vaccine 22:3-4 (January 2, 2004), pp. 362-369; doi 10.1016/j.vaccine.2003.08.007

Copyright (C) 2003 Elsevier Ltd. Used by permission. http://www.sciencedirect.com/science/journal/o264410X

Submitted May 8, 2003; revised August 6, 2003; accepted August 8, 2003; published online September 5, 2003.

\title{
Decreased shedding of Escherichia coli $0157: \mathrm{H} 7$ by cattle following vaccination with type III secreted proteins
}

\author{
Andrew A. Potter ${ }^{1}$, Sandra Klashinsky ${ }^{1}$, Yuling Li², Elizabeth Frey ${ }^{2}$, Hugh Townsend ${ }^{1}$, \\ Dragan Rogan³, Galen Erickson4, Susanne Hinkley4, Terry Klopfenstein ${ }^{4}$, \\ Rodney A. Moxley4 ${ }^{4}$ David R. Smith4, and B. Brett Finlay ${ }^{2}$
}

\footnotetext{
${ }^{1}$ Vaccine and Infectious Disease Organization, University of Saskatchewan, Saskatoon, SK, Canada S7N 5E3

${ }^{2}$ Biotechnology Laboratory, \# 237-6174 University Blvd., University of British Columbia, Vancouver BC, Canada V6T 1Z3

3 Bioniche Life Sciences, Belleville, Ont., Canada K8N 1E2

4 Institute of Agriculture and Natural Resources, University of Nebraska-Lincoln, Lincoln, NE 68538-0905, USA
}

Corresponding author-B. B. Finlay, bfinlay@interchange.ubc.ca

\begin{abstract}
Cattle are an important reservoir of Escherichia coli $\mathrm{O} 157: \mathrm{H} 7$ leading to contamination of food and water, and subsequent human disease. This pathogen colonizes its hosts by producing several proteins such as Tir and EspA that are secreted by a type III secretion system. These proteins play a role in colonization of the intestine, suggesting that they might be useful targets for the development of a vaccine to reduce levels of this organism in cattle. Vaccination of cattle with proteins secreted by $E$. coli $\mathrm{O}_{157: \mathrm{H} 7}$ significantly reduced the numbers of bacteria shed in feces, the numbers of animals that shed, and the duration of shedding in an experimental challenge model. Vaccination of cattle also significantly $(P=0.04)$ reduced the prevalence of $E$. coli $\mathrm{O}_{157}: \mathrm{H} 7 \mathrm{in}$ a clinical trial conducted in a typical feedlot setting. This strategy suggests it is possible to vaccinate cattle to decrease the level of E. coli O157:H7 shedding for the purpose of reducing the risk of human disease.
\end{abstract}

Keywords: Enterohemorrhagic Escherichia coli, EHEC, O157:H7, bovine vaccine

\section{Introduction}

Enterohemorrhagic Escherichia coli (EHEC) is an important zoonotic pathogen of humans, causing severe diarrhea (hemorrhagic colitis) and in a small percentage of cases, haemolytic-uremic syndrome (HUS). There are approximately 75,00o infections and 61 deaths/year in the USA [1]. Unfortunately, antibiotics increase the risk of HUS [2], and there are no current therapies for EHEC human infections other than general supportive measures [3]. EHEC serotype O157:H7 causes 85-95\% of the cases of HUS in North America [4], and is also the leading cause of HUS in Europe [3].

Cattle are an important reservoir for E. coli O157:H7 and many human infections are attributable to contact with contaminated meat or other sources, such as water, fruit or vegetables [4]. This organism can be found in $80 \%$ of some populations of live cattle [5], and 49\% of beef carcasses [6], respectively. It does not appear to cause disease in adult cattle, although it can cause diarrhea in neonates [7]. Serologic evidence suggests that most calves are exposed to $E$. coli O157:H7 [8]. The number of animals shedding the organism in their feces is usually higher in the summer months [9], which correlates with an increased incidence of human disease. Shedding is intermittent, but it is not known if the organism remains in the intestines of cattle during periods of time when it cannot be recovered from feces.

Since cattle and their products are associated with the majority of cases of $E$. coli $\mathrm{O} 157: \mathrm{H}_{7}$ infection in humans, they represent an attractive target for pre-slaughter intervention as a means of reducing risk to humans. A number of approaches are being studied to reduce levels of the organism in cattle, including animal management practices such as chlorination of water [10], modifications to animal feed [11-13], the use of probiotics [14], and bacteriophage therapy [15]. Other vaccinations are also being investigated [16-18].

Proteins secreted by the type III system play a role in colonization of non-bovine hosts by E. coli O157:H7 [19], 
and it is likely they are also required for colonization of the bovine intestine. One virulence determinant, Tir, is integrated into the host cell membrane where it serves as the receptor for the bacterial outer membrane protein, intimin [19]. Tir-intimin binding is essential for bacterial adherence to host cells [19-21]. Proteins secreted via the type III pathway, including Tir, EspA (which forms a linkage between bacterium and host cell), and EspB (which forms a pore in the host cell), are recognized by sera from convalescent individuals [22]. Dean-Nystrom et al. [20] demonstrated that intimin is required for the development of attaching-effacing (A/E) lesions in neonatal calves, and that pedestals (protrusions beneath adherent bacteria mediated by type III effectors such as Tir) are present in infected ileal tissue. Baehler and Moxley [23], by inoculating explants prepared from 18-month-old slaughtered steers, demonstrated that adult bovine colonic and rectal epithelia are susceptible to E. coli $\mathrm{O}_{157: \mathrm{H} 7}$ induced A/E lesions. Subsequent studies, based on experimental inoculation of adult cattle, demonstrated that expression of intimin [24] and Tir [25] are required for E. coli $\mathrm{O}_{157: \mathrm{H}_{7}}$ intestinal colonization. A study in swine demonstrated the potential for protection against $\mathrm{A} / \mathrm{E}$ lesions and intestinal colonization by vaccination with intimin [26]. Collectively, these observations suggest that the type III secreted proteins are attractive targets for vaccine development.

\section{Materials and methods}

\subsection{Bacterial strains and culture conditions}

The E. coli $\mathrm{O} 157: \mathrm{H} 7$ strain used for the production of type III secreted proteins and experimental infection was originally obtained from Li et al. [22] and Tarr et al. [27] and the tir mutant was described by Li et al. [22]. Recombinant E. coli K12 strains used for the production of Tir and EspA were as described [22].

\subsection{Preparation of type III secreted proteins and vaccine formulation}

Supernatant proteins [containing type III secreted proteins (Esps and Tir)] were prepared from E. coli $\mathrm{O} 157: \mathrm{H} 7$ precisely as described [22], and formulated with the adjuvant VSA3 [28] such that the protein concentration was either 25 or $100 \mu \mathrm{g} / \mathrm{ml}$.

\subsection{Vaccination and experimental infection of cattle}

Calves and yearling cattle were obtained from farms in Saskatchewan, Canada and were housed at the University of Saskatchewan. They were fed a barley-based finishing ration with free choice roughage. All animals were screened prior to immunization for existing serum antibody titres against EHEC secreted proteins as well as shedding of $E$. coli O157: H7. Animals which had existing titres or which were shedding the organism at any point prior to experimental chal- lenge were excluded from the study and were moved to separate housing to avoid cross-contamination. Cattle were immunized with $2 \mathrm{ml}$ of each vaccine formulation delivered subcutaneously in the neck. In all experiments, a control vaccine group that received a formulation containing adjuvant only was included. Animals were challenged 2 weeks following the last immunization with $10^{8} \mathrm{CFU}$ of $E$. coli $\mathrm{O} 157: \mathrm{H} 7$ by oral-gastric intubation and fecal shedding of the organism was monitored for 14 days. In the first experiment described below, eight seronegative 6-month-old calves were vaccinated twice with $2 \mathrm{ml}$ of the vaccine formulation $(100 \mu \mathrm{g} / \mathrm{ml})$ by the subcutaneous route, while an equal number of age-matched calves received a placebo containing adjuvant but no antigen. Bacteria were detected by direct plating of fecal samples which had been resuspended in saline on Sorbitol MacConkey agar supplemented with cefixime and tellurite [29]. A second vaccine trial was designed in which three groups of yearling (adult) cattle were immunized as described above three times with $50 \mu \mathrm{g}$ of supernatant $(n=13), 50 \mu \mathrm{g}$ of secreted proteins from a tir mutant [19] $(\Delta \operatorname{Tir}, n=10)$ or a placebo $(n=25)$ on days 0,21 , and 35 . Fecal samples from yearling cattle were cultured after immunomagnetic enrichment [29 and 30] as well as direct plating. The immune response following immunization was measured using serum samples taken at the time of each vaccination by an enzyme-linked immunosorbent assay [31] and by Western blotting [22]. Differences in outcome variables between or among vaccine groups were assessed using the Wilcoxon Rank Sum Test or the Kruskal-Wallis ANOVA, as appropriate. These differences were considered significant whenever $P<0.05$. This model typically results in measurable shedding of the organism for a period of approximately 60 days. All animal experiments were conducted in accordance with the guidelines established by the Canadian Council for Animal Care.

\subsection{Protection against natural exposure to E. coli O157: $\mathrm{H} 7$}

One hundred and ninety-two steers were blocked by weight, stratified by weight within block and assigned randomly to 24 pens on 11 May 2002. The cattle were housed in outdoor dirt-floored pens with a stocking density of 28 square meters of floor-space per animal. The finishing diet of $54.5 \%$ high moisture corn, $35 \%$ wet corn gluten feed, $5 \%$ corn silage, $2.5 \%$ alfalfa hay, and $3 \%$ supplement was used for all animals. The treatments (vaccination, yes or no) were randomly allocated to four pens within each of three weight blocks for a total of twelve repetitions per treatment. The treatments were initiated (treatment day o) 9, 17, and 23 days after cattle arrived in the feedyard for blocks 1, 2, and 3 , respectively. The vaccine was the same as described

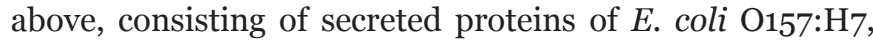
and was administered subcutaneously $(50 \mu \mathrm{g} / \mathrm{dose})$ to cattle within assigned pens on treatment days 0,21 , and 42 of each block. Cattle within the control pens received an injection of adjuvant on the same schedule as vaccinated cattle. 
Table 1. Oligonucleotide primers used in multiplex PCR to confirm identity of isolates as E. coli O157:H7

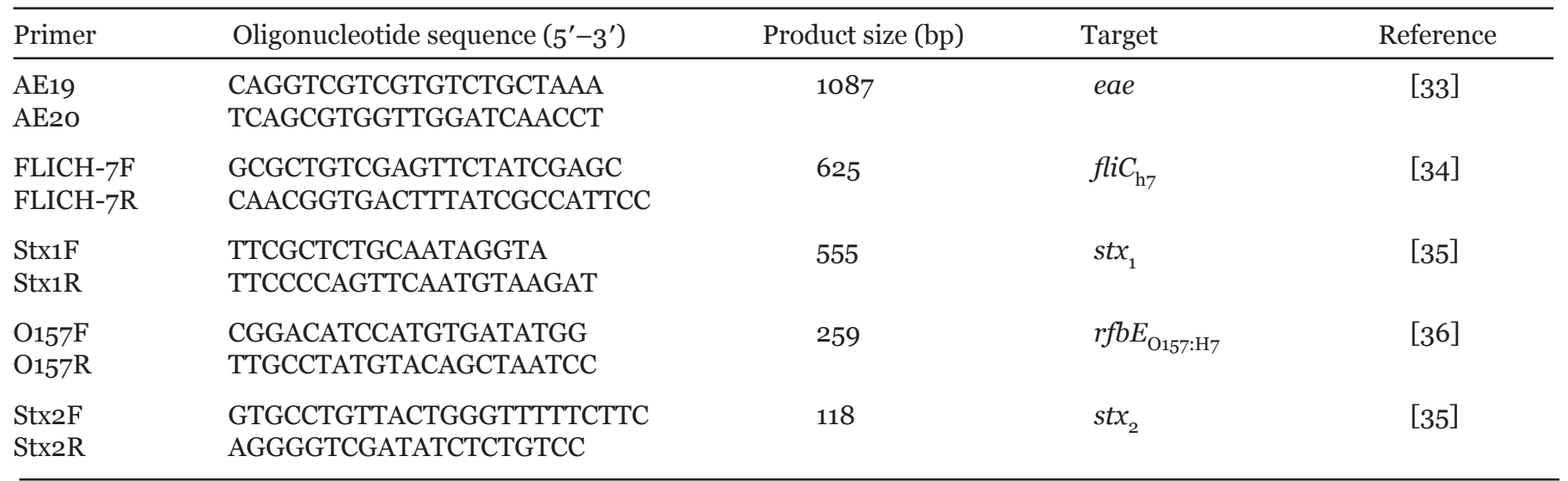

Samples of rectal feces were collected for bacterial culture from cattle within each block on treatment days $0,21,42$, 63,84 , and the day of marketing (treatment days 106, 104, and 105 of blocks 1, 2, and 3, respectively).

Outcome measures were pen-level performance and the proportion of animals per pen culture-positive for $E$. coli O157:H7. Feedlot performance and E. coli O157:H7 culture outcomes were analyzed after arcsine transformation of the proportions accounting for block as a random effect and repeated sampling for E. coli $\mathrm{O} 157: \mathrm{H} 7$.

Fecal samples were cultured for E. coli $\mathrm{O}_{157: \mathrm{H}_{7}}$ as previously described [5] with modifications. Ten grams fecal samples were incubated $6 \mathrm{~h}$ in $90 \mathrm{ml}$ Gram-negative (GN) broth containing $8 \mu \mathrm{g} / \mathrm{ml}$ vancomycin, $0.05 \mu \mathrm{g} / \mathrm{ml}$ cefixime, and $10 \mu \mathrm{g} / \mathrm{ml}$ cefsulodin. One $\mathrm{ml}$ of this culture was subjected to O157 immunomagnetic separation (Dynal, Lake Success, NY), and $20 \mu$ of the bead-bacteria mixture was spread onto sorbitol-MacConkey plates containing cefixime $(0.05 \mu \mathrm{g} / \mathrm{ml})$ and potassium tellurite $(2.5 \mu \mathrm{g} / \mathrm{ml}$; CT-SMAC) and cultured overnight. Individual sorbitolnonfermenting colonies were subcultured for isolation on CT-SMAC plates, and an individual sorbitol-nonfermenting colony from each plate was inoculated onto both MacConkey and Fluorocult (EM Science, Gibbstown, NJ) agars. Isolates that fermented lactose but not sorbitol within $24 \mathrm{~h}$ and had a negative 4-methylumbelliferyl- $\beta$-D -glucuronide (MUG) reaction were streaked for isolation on blood agar plates. Following overnight incubation, one colony per isolate from a blood agar plate was tested for E. coli O157 and $\mathrm{H} 7$ antigens by latex agglutination (Remel, Lenexa, KS).

Isolates that were positive for O157 antigen by latex agglutination (regardless of $\mathrm{H}_{7}$ results) were tested in a five primer-pair multiplex polymerase chain reaction (PCR) assay that detected genes for $E$. coli $\mathrm{O} 157\left(r f b E_{\mathrm{O} 157: \mathrm{H} 7}\right)$, $\mathrm{H} 7\left(\right.$ fli $\left._{\mathrm{h}}\right)$, Shigatoxins $1\left(s t x_{1}\right)$ and $2\left(s t x_{2}\right)$, and intimin (eae). For PCR amplification, cells from an individual colony on blood agar were transferred into a $1.5 \mathrm{ml}$ Eppendorf tube containing $50 \mu \mathrm{l}$ sterile nuclease-free water and incubated at $100{ }^{\circ} \mathrm{C}$ for $6 \mathrm{~min}$. The tube was then centrifuged at $2000 \mathrm{rpm}$ for $2 \mathrm{~min}$ in a microfuge and the supernatant used as template. For each assay, template prepared from E. coli $\mathrm{O} 157: \mathrm{H} 7$ strain EDL933 (ATCC \# 43895) was used as a positive control, and one lacking any template was used as a negative control. The PCR was conducted in a $50 \mu \mathrm{l}$ reaction mixture containing $2 \mu \mathrm{l}$ template DNA, $10 \mathrm{mM}$ Tris$\mathrm{HCl}$ (pH 8.4), $50 \mathrm{mM} \mathrm{KCl,} 2.5 \mathrm{mM} \mathrm{MgCl}_{2}, 200 \mu \mathrm{M}$ of each dNTP (Promega, Madison WI), and 1.5 U Taq DNA polymerase (Promega). Oligonucleotide primers (Table 1) were used at the following concentrations: $0.5 \mu \mathrm{M}$ for those targeting the eae, st $x_{1}, s t x_{2}$, and $r f b E_{\mathrm{O}_{157: \mathrm{H} 7}}$ genes, and $0.2 \mu \mathrm{M}$ for those targeting the $f \mathrm{C}_{\mathrm{h} 7}$ gene. Samples were amplified in a PTC-200 DNA engine (MJ Research Inc., Incline Village, NV) under the following cycling conditions. Conditions included an initial denaturation step of 5 min at $94{ }^{\circ} \mathrm{C}$, followed by 34 cycles with denaturing at $94{ }^{\circ} \mathrm{C}$ for $45 \mathrm{~s}$, annealing at $50{ }^{\circ} \mathrm{C}$ for $30 \mathrm{~s}$, and extension at $72{ }^{\circ} \mathrm{C}$ for $90 \mathrm{~s}$. The final cycle consisted of extension for $10 \mathrm{~min}$ at $72{ }^{\circ} \mathrm{C}$, ramping to $50^{\circ} \mathrm{C}$ at $0.1{ }^{\circ} \mathrm{C} / \mathrm{s}$, holding $50{ }^{\circ} \mathrm{C}$ for $5 \mathrm{~min}$, ramping to $4{ }^{\circ} \mathrm{C}$ at $0.2{ }^{\circ} \mathrm{C} / \mathrm{s}$, and soaking at $4{ }^{\circ} \mathrm{C}$. Samples were analyzed by standard agarose gel electrophoresis $(10 \mu \mathrm{l}$ per sample) on a $1.3 \%$ gel, stained with ethidium bromide, and then visualized under UV illumination. DNA molecular size standards (PCR marker, Promega, Madison WI) and positive and negative controls were included in every run.

\section{Results}

To test the vaccine potential of secreted proteins, supernatant proteins [containing type III secreted proteins (Esps and Tir)] were prepared from E. coli $\mathrm{O}_{157: \mathrm{H} 7}$, formulated at a dose of $100 \mathrm{ug} / \mathrm{ml}$ and used to vaccinate eight calves. A second group of calves which received a placebo vaccine was also included. The group that received the EHEC vaccine showed a 13-fold increase in specific antibody titre to type III secreted proteins after a single immunization, and after a booster vaccination on day 21, the EHEC vaccine group demonstrated a 45 -fold increase in specific antibody titre while only one of the placebo vaccine group seroconverted $\left(\chi^{2}, P=0.0002\right)$. On each of the post-challenge days, 


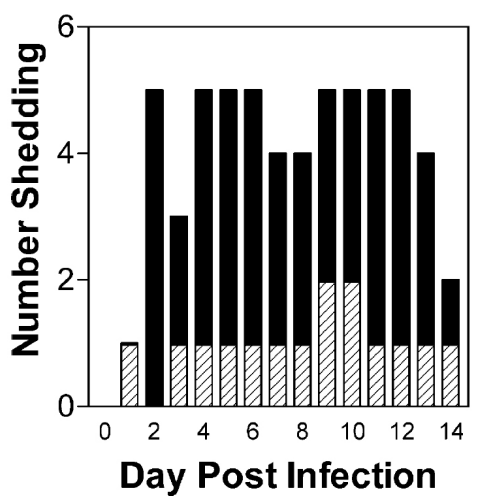

Figure 1. Number of calves shedding E. coli $\mathrm{O} 157: \mathrm{H} 7$ on each day following experimental challenge. The strain used for infection [22-27] was grown to mid-exponential phase as described [22]. Bacteria were detected by direct plating of fecal samples that had been resuspended in saline on Sorbitol MacConkey agar supplemented with cefixime and tellurite [29]. Solid bars, placebo group; hatched bars, EHEC vaccine group.

fewer EHEC-vaccinated animals shed bacteria compared to the placebo group (Figure 1). Seven of eight placebo-immunized animals shed the bacteria during the trial and four of those animals shed for four or more consecutive days. Five of eight EHEC vaccine-immunized animals shed the bacteria at some point during the trial, but only one shed for more than two consecutive days, indicating that colonization was transient and significantly less than the placebo group. The total number of bacteria isolated from fecal samples was significantly lower among the EHEC-vaccinated group as compared to the placebo group (Wilcoxon Rank Sum Test, $P=0.05$ ), with the former having a median of 6.25 colony forming units (CFU) per gram of feces recovered compared to a median value of $81.25 \mathrm{CFU} / \mathrm{g}$ for the latter.

No significant differences in anti-EHEC, anti-Tir or anti-EspA responses were observed between groups of six calves immunized with 50,100 , or $200 \mu \mathrm{g}$ of supernatant, but all three were significantly higher than the placebo group on days 21 (boost) and 35 [25]. Thus, a second vaccine trial was conducted in which three groups of yearling cattle were immunized with supernatant prepared from the wild-type strain $(n=13)$, from a tir mutant [19] ( $\Delta$ Tir, $n=10)$ or a placebo $(n=25)$ on days 0,21 , and 35 , followed by oral challenge with $E$. coli $\mathrm{O} 157: \mathrm{H} 7$ on day 49. The group that received the $\Delta$ Tir vaccine showed a response of similar magnitude against total secreted proteins as the group that received the vaccine prepared from the wild-type strain, but, as expected, a significantly reduced response to Tir (Wilcoxon Rank Sum Test, $P=0.006$ ) (Table 2). However, the former group did show an increase in anti-Tir antibody levels (Wilcoxon Rank Sum Test, $P=0.009$ ), indicating either exposure to an organism producing an immunologically-related molecule or natural exposure to E. coli O157: $\mathrm{H}_{7}$. This is further supported by the observation that there was an increase in the anti-Tir antibody titre in the placebo group on the day of challenge (Wilcoxon Rank Sum Test, $P=0.002)$ but no difference between the placebo or $\Delta$ Tir groups ( $P=0.37$, Kruskal-Wallis ANOVA). The response to EspA, a type III secreted protein, was similar in both the EHEC and $\triangle$ Tir vaccine groups $(P=0.45$, Kruskal-Wallis ANOVA) and was significantly higher than the placebo-immunized animals $(P<0.0001)$.

The proteins secreted by the type III system were highly immunogenic in cattle (Figure 2). EspB, EspD and Tir were all reactive and after the second immunization on day 21, a significant response against lipopolysaccharide was also observed. The kinetics of the immune response in a vaccinated animal (Figure 2, bottom panels) show that anti-Tir antibodies were detectable following a single immunization, as were antibodies against 43 and $100 \mathrm{kDa}$ proteins. The latter proteins were produced by the wild-type strain as well as the $\operatorname{sep} B$ and tir mutants and the $100 \mathrm{kDa}$ protein is probably EspP, a non-type III EHEC secreted protein.

After oral challenge with E. coli $\mathrm{O} 157: \mathrm{H}_{7}$ on day 49, each group was monitored daily for fecal shedding of the organism for 14 days. In this experiment, bacteria were cultured after immunomagnetic enrichment $[29,30]$ rather than direct plating as yearling cattle shed less than calves in this infection model. On the day of challenge, two animals in the placebo group were culture-positive for E. coli O157: $\mathrm{H}_{7}$ and were eliminated from the trial. The placebo-immunized animals shed the organism after challenge much more than those in the two EHEC vaccine groups (Figure 3). Animals receiving the placebo shed the organism for a median of 4 days, significantly longer than the median of $o$ day by the other two vaccine groups $(P=0.0002$, KruskalWallis ANOVA). Significantly fewer bacteria were recovered from the EHEC and $\triangle$ Tir vaccine groups $(P=0.04$, KruskalWallis ANOVA). From day 2 post-infection onwards, $78.3 \%$ of the placebo animals (18 of 23 animals) shed the organ-

Table 2. Median serological response of yearling cattle to immunization with secreted proteins prepared from wild-type E. coli O157:H7 (EHEC), an isogenic tir mutant ( $\Delta$ Tir) or a placebo.

\begin{tabular}{|c|c|c|c|c|c|c|c|}
\hline \multirow[t]{2}{*}{ Group } & \multirow[t]{2}{*}{$N$} & \multicolumn{2}{|l|}{ Anti-EHEC } & \multicolumn{2}{|l|}{ Anti-Tir } & \multicolumn{2}{|l|}{ Anti-EspA } \\
\hline & & Day o & Day 49 & Day o & Day 49 & Day o & Day 49 \\
\hline EHEC & 13 & $10(10-100)$ & $6400(3200-12800)$ & $100(10-200)$ & $1600(800-3200)$ & $100(10-200)$ & $400(200-1600)$ \\
\hline Placebo & 25 & $10(10-200)$ & $10(10-200)$ & $100(10-200)$ & $200(10-400)$ & $100(10-200)$ & $100(10-200)$ \\
\hline
\end{tabular}

Titres are expressed as median values of the last positive dilution of sera [31]. Numbers in parentheses represent the 25th-75th percentile. 

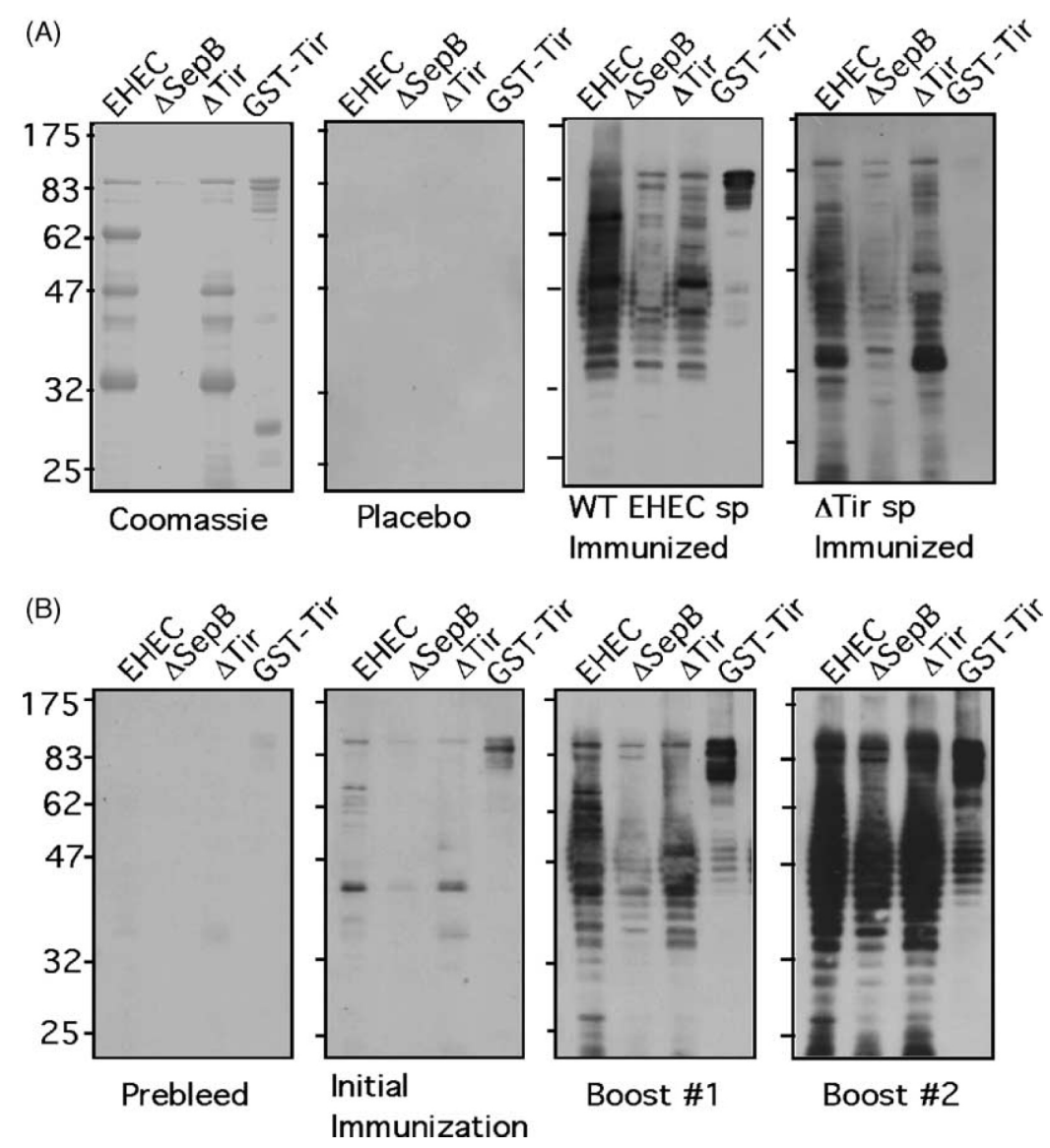

Figure 2. Immunoblot analysis of sera from vaccinated yearling cattle against EHEC secreted proteins. Each blot contains secreted proteins from wild-type $E$. coli $\mathrm{O}_{157}: \mathrm{H} 7$ (EHEC), type III secretion mutant $(\Delta \mathrm{SepB})$, tir mutant $(\Delta \mathrm{Tir})$ and a purified glutathione-s-transferase:Tir fusion protein (GST-Tir). Proteins were separated by SDS-10\% PAGE and stained with Coomassie blue (A, upper left panel) or transferred to nitrocellulose and probed with representative sera from animals which received three immunizations with each vaccine formulation (A). The lower four panels (B) were probed with sera from one representative animal which received the EHEC vaccine, taken on days o, 21, 35 and 49 of the trial (prebleed, after initial immunization, after boost \#1, after boost \#2, respectively).

ism for at least 1 day as compared to $15.4 \%$ of the EHEC ( 2 of $13, P=0.003$ ) and $30 \%$ ( 3 of $10, P=0.008$ ) of the $\Delta$ Tir vaccinates.

To determine whether vaccination would have an effect on E. coli $\mathrm{O}_{157}: \mathrm{H}_{7}$ infection occurring from natural exposure, a clinical trial was conducted. Specifically, the trial evaluated the effect of vaccination on the proportion of feedlot steers shedding $E$. coli $\mathrm{O}_{157: \mathrm{H} 7}$ in their feces in typical feedlot conditions of exposure. Treatment groups did not differ in performance (viz. average daily gain, dry matter intake, gain to feed, marbling score, fat thickness, or yield grade).

The pre-treatment prevalence of animals shedding $E$. coli $\mathrm{O} 157: \mathrm{H} 7$ averaged $30 \%$, and did not differ significantly between treatments $(P=0.66)$. The average proportion of cattle shedding $E$. coli $\mathrm{O}_{157}$ :H7 differed $(P=0.04)$ over the five test-periods (treatment days $21,42,63,84$, and the day of marketing; 24, 10.9, 13.0, 5.7, and 21.4\%, respectively); however, no interaction was observed between treatment and test-period $(P=0.62)$. The average proportion of cattle shedding E. coli $\mathrm{O} 157: \mathrm{H} 7$ in vaccine treated pens (8.8\%) was significantly less $(P=0.04)$ than in non-vaccinated pens of cattle (21.3\%) (Figure 4). A total of 362 E. coli $\mathrm{O}_{157: \mathrm{H} 7}$ isolates were obtained from the cattle in this clinical trial. By the five primer-pair multiplex PCR, all isolates were positive for the $\mathrm{rfbE}$ and $\mathrm{fliC}_{\mathrm{h} 7}$ genes; 315 isolates were also positive for the $s t x_{2}$ and eae genes, but negative for $s t x_{1} ; 42$ isolates were positive for all five genes.

\section{Discussion}

The data presented above demonstrate that virulence factors secreted by the type III system can be used as effective vaccine components for the reduction of colonization of cattle by $E$. coli $\mathrm{O}_{157: \mathrm{H} 7}$ in an experimental challenge model, and in a clinical trial testing under conditions of natural exposure within a feedlot setting. These proteins are major targets of the immune response in humans following infection [22], although calves do not usually mount a significant serological response against these proteins following natural exposure to the organism. However, cattle 

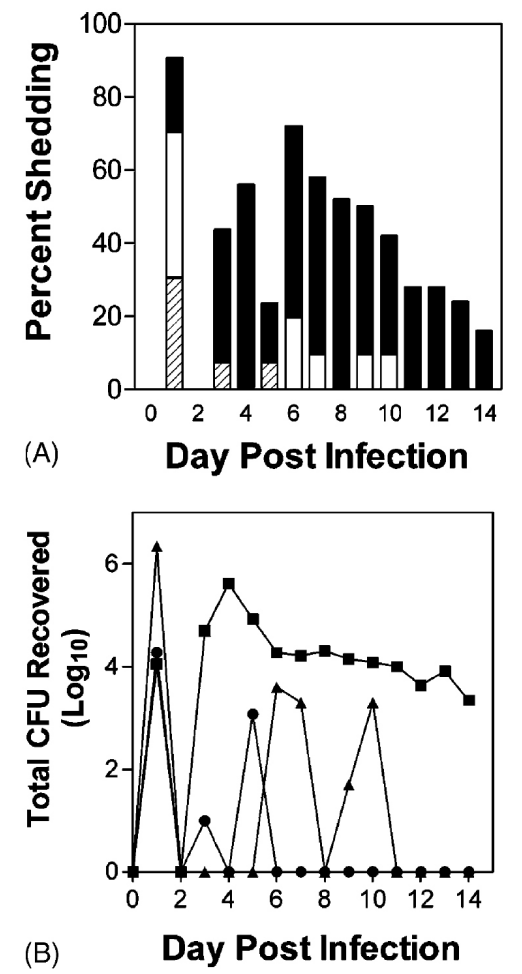

Figure 3. Percentage of each group of yearling cattle shedding $E$. coli O157:H7 (A) and total number of bacteria recovered (B) on each day after experimental infection. Bacteria were detected in feces by plating on Sorbitol MacConkey agar supplemented with cefixime and tellurite following immunomagnetic enrichment as described [29]. (A) Solid bars, placebo; hatched bars, EHEC vaccine; open bars, $\Delta$ Tir vaccine. (B) Squares, placebo group; circles, EHEC vaccine; triangles, $\Delta$ Tir vaccine.

vaccinated with these proteins are primed and show an increase in anti-EHEC and anti-Tir titres following oral challenge with the organism [25].

Tir is likely required for colonization of the bovine intestine [25], and this is supported by the observation that a vaccine containing secreted proteins from a $\Delta$ Tir $E$. coli O157: $\mathrm{H} 7$ strain was not as efficacious as an identical formulation from an isogenic wild-type isolate. However, the former vaccine was significantly more efficacious than a placebo suggesting that immunity against colonization is multifactorial in nature. This is supported by the Western blot analysis of the response to immunization in which several protein components as well as lipopolysaccharide were recognized.

The clinical trial was conducted under conditions of natural exposure in an environment typical of feedyards in the Central US and Canada. The prevalence of $E$. coli O157: $\mathrm{H} 7$ shedding observed among all of the cattle at the beginning of the trial and among control group cattle throughout the trial was typical of that previously observed in both research [32] and commercial feedyards [5]. During the trial, the prevalence of cattle shedding E. coli $\mathrm{O} 157: \mathrm{H} 7$ varied over time within both treatment groups.

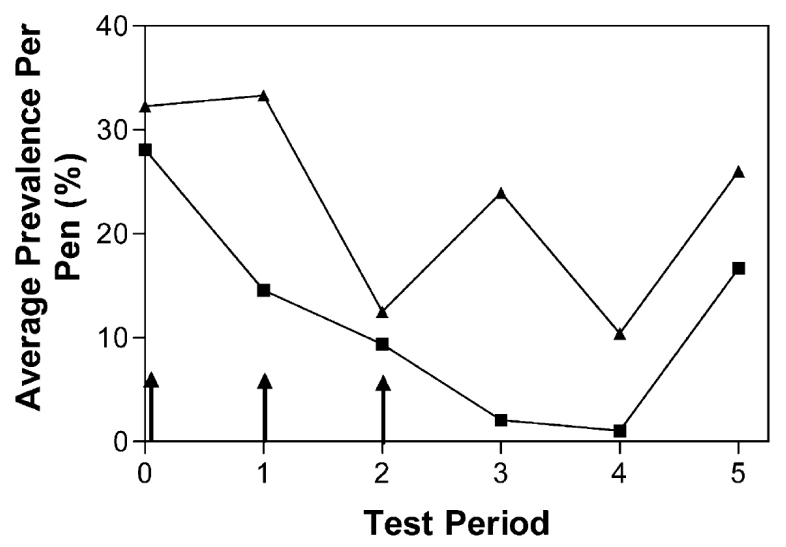

Figure 4. The proportion of cattle shedding E. coli $\mathrm{O} 157: \mathrm{H} 7$ within pens of vaccinated and unvaccinated cattle in conditions of natural exposure. Arrows indicate the time of vaccination. Test-periods represent the day of sampling at 3 week intervals (treatment days $0,21,42$, 63,84 , and the day of marketing), with o representing sampling prior to the first vaccination. Triangles, unvaccinated controls; squares, vaccinated animals.

Longitudinal studies have documented that within the same group of cattle the proportion of cattle shedding $E$. coli $\mathrm{O} 157: \mathrm{H} 7$ can vary greatly $(1-80 \%)$ over the course of the feeding period [32]. In this study, even though prevalence of shedding varied by time period, vaccination resulted in proportionately less shedding in the five test-periods compared to controls. Three doses of vaccine were administered during the clinical trial; however, it is not clear that all three doses were necessary for effect. The prevalence of shedding was observed to decrease following the first vaccination in the clinical trial. Also, no interaction was observed between treatments and test-periods suggesting that the effect of vaccine on fecal shedding did not differ after the first vaccination. The issue is of practical importance since feedlot operators may be challenged to comply with the need to repeatedly vaccinate cattle, and greater numbers of doses increase the cost of feedlot cattle production. Therefore, the most efficient number of vaccine doses must be tested in additional studies. However, the results of the first vaccine trial in calves described above suggests that a schedule of two immunizations would be sufficient to significantly reduce the numbers of animals shedding the organism.

The prevalence of non-O157 serotypes in North America appears to be increasing and represents a significant portion of EHEC infections in other geographical locations. Since the type III secreted antigens are relatively conserved among non-O157 EHEC serotypes, this vaccine formulation might be broadly cross-protective, in contrast to formulations based upon the specific O157 LPS antigen. The vaccine described here is relatively simple and economical to prepare, an essential requirement for any bovine vaccine. In addition, it emphasizes the feasibility of vaccinating an animal reservoir to potentially decrease human infections. 


\section{Acknowledgments}

This research was supported by grants from the Beef Industry Development Fund, Alberta Agricultural Research Institute Strategic Emerging Issues Program, Canadian Bacterial Diseases Network Centre of Excellence, Bioniche Life Sciences, ID Biomedical, Alberta Research Council, Howard Hughes Medical Institute (HHMI), National Science and Engineering Research Council (NSERC), Canadian Institutes of Health Research (CIHR), United States Department of Agriculture (NRI-CGP 2000-02501 and 2001-02966) and the Nebraska Beef Council. BBF is a CIHR Distinguished Investigator, a HHMI International Scholar, and the UBC Peter Wall Distinguished Professor. We thank D. Wilson and the staff at VIDO and UNL for assistance with the vaccine trials. Published with the permission of the Director of VIDO. A contribution of the University of Nebraska Agricultural Research Division, Lincoln, NE 68583. Journal series no. 13929.

\section{References}

1. P.S. Mead, L. Slutsker, V. Dietz et al., Food-related illness and death in the United States. Emerg. Infect. Dis. 55 (1999), pp. 607-625.

2. C.S. Wong, S. Jelacic, R.L. Habeeb, S.L. Watkins and P.I. Tarr, The risk of the hemolytic-uremic syndrome after antibiotic treatment of Escherichia coli $\mathrm{O}_{157: \mathrm{H} 7}$ infections. N. Engl. J. Med. 34226 (2000), pp. 1930-1936.

3. R.E. Besser, P.M. Griffin and L. Slutsker, Escherichia coli O157:H7 gastroenteritis and the hemolytic uremic syndrome: an emerging infectious disease. Annu. Rev. Med. 50 (1999), pp. 355-367.

4. G.L. Armstrong, J. Hollingsworth and J.G. Morris, Jr., Emerging foodborne pathogens: Escherichia coli O157: $\mathrm{H}_{7}$ as a model of entry of a new pathogen into the food supply of the developed world. Epidemiol. Rev. 181 (1996), pp. 29-51.

5. D.R. Smith, M. Blackford, S. Younts et al., Ecological relationships between the prevalence of cattle shedding Escherichia coli $\mathrm{O}_{157}: \mathrm{H}_{7}$ and characteristics of the cattle or conditions of the feedlot pen. J. Food Prot. 64 (2001), p. 1899.

6. R.O. Elder, J.E. Keen, G.R. Siragusa, G.A. Barkocy-Gallagher, M. Koohmaraie and W.W. Laegreid, Correlation of enterohemorrhagic E. coli O157 prevalence in feces hides, and carcasses of beef cattle during processing. Proc. Natl. Acad. Sci. U.S.A. 977 (2000), pp. 2999-3003.

7. E.A. Dean-Nystrom, B.T. Bosworth, W.C. Cray, Jr. and H.W. Moon, Pathogenicity of E. coli O157:H7 in the intestines of neonatal calves. Infect. Immun. 655 (1997), pp. 1842-1848.

8. W.W. Laegreid, R.O. Elder and J.E. Keen, Prevalence of Escherichia coli O157:H7 in range beef calves at weaning. Epidemiol. Infect. 1232 (1999), pp. 291-298.

9. J. VanDonkersgoed, T. Graham and V. Gannon, The prevalence of verotoxins, E. coli 0157:H7, and Salmonella in the feces and rumen of cattle at processing. Can. Vet. J. 405 (1999), pp. 332-338.
10. E.W. Rice, R.M. Clark and C.H. Johnson, Chlorine inactivation of E. coli O157:H7. Emerg. Infect. Dis. 53 (1999), pp. 461-463.

11. J.B. Russell, F. Diez-Gonzalez and G.N. Jarvis, Potential effect of cattle diets on the transmission of pathogenic $E$. coli to humans. Microbes Infect. 21 (2000), pp. 45-53.

12. F. Diez-Gonzalez, T.R. Callaway, M.G. Kizoulis and J.B. Russell, Grain feeding and the dissemination of acid-resistant E. coli from cattle. Science $\mathbf{2 8 1} 5383$ (1998), pp. 1666-1668.

13. S.J. Buchko, R.A. Holley, W.O. Olson, V.P. Gannon and D.M. Veira, The effect of different grain diets on fecal shedding of E. coli O157:H7 by steers. J. Food Prot. 6311 (2000), pp. 1467-1474.

14. T. Zhao, M.P. Doyle, B.G. Harmon, C.A. Brown, P.O. Mueller and A.H. Parks, Reduction of carriage of enterohemorrhagic $E$. coli $\mathrm{O} 157: \mathrm{H} 7$ in cattle by inoculation with probiotic bacteria. J. Clin. Microbiol. 363 (1998), pp. 641-647.

15. I.T. Kudva, S. Jelacic, P.I. Tarr, P. Youderian and C.J. Hovde, Biocontrol of E. coli O157 with O157-specific bacteriophages. Appl. Environ. Microbiol. 659 (1999), pp. 3767-3773.

16. J.W. Conlan, R. KuoLee, A. Webb and M.B. Perry, Salmonella landau as a live vaccine against $E$. coli O157:H7 investigated in a mouse model of intestinal colonization. Can. J. Microbiol. 459 (1999), pp. 723-731.

17. J.W. Conlan, R. KuoLee, A. Webb, A.D. Cox and M.B. Perry, Oral immunization of mice with a glycoconjugate vaccine containing the $\mathrm{O} 157$ antigen of $E$. coli $\mathrm{O} 157: \mathrm{H} 7$ admixed with cholera toxin fails to elicit protection against subsequent colonization by the pathogen. Can. J. Microbiol. 46 3 (2000), pp. 283-290.

18. J.W. Conlan, A.D. Cox, R. KuoLee, A. Webb and M.B. Perry, Parenteral immunization with a glycoconjugate vaccine containing the $\mathrm{O} 157$ antigen of $E$. coli $\mathrm{O}_{157}: \mathrm{H} 7$ elicits a systemic humoral immune response in mice, but fails to prevent colonization by the pathogen. Can. J. Microbiol. 454 (1999), pp. 279-286.

19. R. DeVinney, M. Stein, D. Reinscheid, A. Abe, S. Ruschkowski and B.B. Finlay, Enterohemorrhagic E. coli O157: $\mathrm{H} 7$ produces Tir, which is translocated to the host cell membrane but is not tyrosine phosphorylated. Infect. Immun. 75 (1999), pp. 2389-2398.

20. E.A. Dean-Nystrom, B.T. Bosworth, H.W. Moon and A.D. O'Brien, E. coli O157:H7 requires intimin for enteropathogenicity in calves. Infect. Immun. 669 (1998), pp. $4560-4563$.

21. S. Tzipori, F. Gunzer, M.S. Donnenberg, L. de Montigny, J.B. Kaper and A. Donohue-Rolfe, The role of the eaeA gene in diarrhea and neurological complications in a gnotobiotic piglet model of enterohemorrhagic $E$. coli infection. Infect. Immun. 639 (1995), pp. 3621-3627.

22. Y. Li, E. Frey, A.M. Mackenzie and B.B. Finlay, Human response to $E$. coli $\mathrm{O} 157: \mathrm{H} 7$ infection: antibodies to secreted virulence factors. Infect. Immun. 689 (2000), pp. 5090-5095. 
23. A.A. Baehler and R.A. Moxley, E. coli $\mathrm{O} 157: \mathrm{H} 7$ induces attaching-effacing lesions in large intestinal mucosal explants from adult cattle. FEMS Microbiol. Lett. 1852 (2000), pp. 239-242.

24. N.A. Cornick, S.L. Booher and H.W. Moon, Intimin facilitates colonization by $E$. coli $\mathrm{O}_{157: \mathrm{H} 7}$ in adult ruminants. Infect. Immun. 705 (2002), pp. 2704-2707.

25. Potter AA, Finlay BB [unpublished].

26. E.A. Dean-Nystrom, L.J. Gansheroff, M. Mills, H.W. Moon and A.D. O'Brien, Vaccination of pregnant dams with intimin (O157) protects suckling piglets from E. coli O157: $\mathrm{H}_{7}$ infection. Infect. Immun. 705 (2002), pp. 2414-2418.

27. P.I. Tarr, M.A. Neill, C.R. Clausen, J.W. Newland, R.J. Neill and S.L. Moseley, Genotypic variation in pathogenic E. coli O157:H7 isolated from patients in Washington 1984-1987. J. Infect. Dis. 1592 (1989), pp. 344-347.

28. S. van Drunen Little-van den Hurk, M.D. Parker, B. Massie et al., Protection of cattle from BHV-1 infection by immunization with recombinant glycoprotein gIV. Vaccine 11 (1993), pp. 25-35.

29. J. VanDonkersgoed, J. Berg and A. Potter, Environmental sources and transmission of E. coli O157 in feedlot cattle. Can. Vet. J. 429 (2001), pp. 714-720.

30. P.A. Chapman and C.A. Siddons, A comparison of immunomagnetic separation and direct culture for the isolation of verocytotoxin-producing E. coli $\mathrm{O} 157$ from cases of bloody diarrhoea. J. Med. Microbiol. 444 (1996), pp. 267-271.
31. A.A. Potter, A.B. Schryvers, J.A. Ogunnariwo, W.A. Hutchins, R.Y. Lo and T. Watts, Protective capacity of the Pasteurella haemolytica transferrin-binding proteins TbpA and TbpB in cattle. Microb. Pathog. 274 (1999), pp. 197-206.

32. Khaitsa ML, Smith DR, Stoner JA, et al. Incidence, duration, and prevalence of Escherichia coli $\mathrm{O}_{157: \mathrm{H}_{7}}$ fecal shedding by feedlot cattle over the feeding period. J Food Prot [in press].

33. V.P. Gannon, M. Rashed, R.K. King and E.J. Thomas, Detection and characterization of the eae gene of Shiga-like toxin-producing $E$. coli using polymerase chain reaction. $J$. Clin. Microbiol. 315 (1993), pp. 1268-1274.

34. V.P. Gannon, S. D’Souza, T. Graham, R.K. King, K. Rahn and S. Read, Use of the flagellar $\mathrm{H}_{7}$ gene as a target in multiplex PCR assays and improved specificity in identification of enterohemorrhagic E. coli strains. J. Clin. Microbiol. 35 3 (1997), pp. 656-662.

35. S.M. Franck, B.T. Bosworth and H.W. Moon, Multiplex PCR for enterotoxigenic, attaching and effacing, and Shiga toxin-producing E. coli strains from calves. J. Clin. Microbiol. 366 (1998), pp. 1795-1797.

36. A.W. Paton and J.C. Paton, Detection and characterization of Shiga toxigenic $E$. coli by using multiplex PCR assays for stx1, stx2, eaeA, enterohemorrhagic E. coli hlyA, rfbO111 and rfbO157. J. Clin. Microbiol. 362 (1998), pp. 598-602. 